\title{
Эколого-гидрогеологическая оценка состояния подземных вод водоносного турон-коньякского карбонатного комплекса в районе села Старая Калитва Россошанского района Воронежской области
}

\author{
(С2020 Д. А. Белозеров ${ }^{\bowtie}$, В. А. Бударина, А. А. Валяльщиков \\ Воронежский государственный университет \\ Университетская пл., 1, 394018, Воронеж, Российская Федерация
}

\begin{abstract}
Аннотация
Введение: Целью исследования является эколого-гидрогеологическая оценка состояния подземных вод водоносного турон-коньякского карбонатного комплекса в районе села Старая Калитва Россошанского района Воронежской области.

Методика: Оценка состояния водоносного турон-коньякского карбонатного комплекса проводилась на основании изучения экологических функций подземных вод. Ресурсная экологическая оценка водоносного турон-коньякского карбонатного комплекса производилась на основании расчета и анализа следующих параметров: литологии водовмещающих пород, мощности водоносного горизонта, глубины залегания подземных вод, положения статического уровня; размеров зон санитарной охраны подземных вод; бактериологических характеристик подземных вод; органолептических характеристик подземных вод. Эколого-гидрогеохимическая оценка водоносного турон-коньякского карбонатного комплекса приводилась на основании сравнения фактических концентраций веществ с предельно-допустимыми концентрациями, расчета средних и максимальных значений суммарного показателя загрязнения. Мониторинг за состоянием качества подземных вод осуществлялся с 2012 по 2019 года. Эколого-геофизическая оценка подземных вод производилась по следующим показателям: удельная суммарная $\alpha$-активность, удельная суммарная $\beta$-активность, удельная активность радона-222. Эколого-гидродинамическая оценка водоносного турон-коньякского карбонатного комплекса производилась на основании расчета основных гидродинамических показателей. Результаты и обсуждение: Для проведения исследовательских работ были использованы 3 разведочно-эксплуатационных скважины глубиной 95 метров каждая. Выявлено, что водовмещающие породы представлены мелами трещинноватыми, мощностью 20 метров, величина напора - 15-19 метров. Размер зон санитарной охраны 1 пояса - 30 м, 2 пояса -86.7 м, 3 пояса 1061.3 м. По результатам оценки выявлено превышение по следующим показателям: мутности (16.6 ПДК), сухому остатку (3.21 ПДК), общей жесткости (4.39 ПДК), хлоридам (4 ПДК), магнию (1.63 ПДК), железу общему (10.7 ПДК). В результате эколого-гидродинамической оценки выявлено, что удельный дебит скважин составляет 0.14 л/с/м, коэффициент водопроводимости - $17 \mathrm{~m}^{2} /$ сут, коэффициент уровнепроводности $10^{4} \mathrm{~m}^{2} /$ сут, допустимое понижение $-27.7 \mathrm{~m}$, расчетное понижение уровня подземных составляет 24.18 м, максимально допустимое водопотребление $-405.09 \mathrm{~m}^{3} / \mathrm{cyт}$. Максимальные превышения содержания загрязняющих веществ в подземных водах отмечаются по концентрации железа - 3.2 мг/дм³ (10.7 ПДК) и суммарному показателю загрязнения, который составляет 10.7 .

Заключение: По результатам проведенной оценки сформирован комплекс природоохранных мероприятий, среди которых одним из основных является: установка системы обратного осмоса для снижения концентрации хлоридов, магния, железа, сухого остатка, а также уменьшения показателей
\end{abstract}

Контент доступен под лицензией Creative Commons Attribution 4.0 License.

\footnotetext{
ॠ Белозеров Денис Александрович, e-mail: belozerovdenis@yandex.ru 
жесткости и мутности. В заключении сделан вывод о проблемах применения существующей теории изучения экологических функций литосферы к оценке экологического состояния подземных вод и необходимости доработки и обеспечения связи учения с реальной ситуацией.

Ключевые слова: подземные воды, водоносный турон-коньякский карбонатный комплекс, экологические функции подземных вод, эколого-гидрогеологическая оценка, качество подземных вод, зоны санитарной охраны, природоохранные мероприятия.

Для циитирования: Белозеров Д. А., Бударина В. А., Валяльщиков А. А. Эколого-гидрогеологическая оценка состояния водоносного турон-коньякского карбонатного комплекса в районе села Старая Калитва Россошанского района Воронежской области // Вестник Воронежского государственного университета. Серия: Геология. 2020. №3. С. 73-89. DOI: https://doi.org/10.17308/geology.2020.3/3011

\section{Введение}

Экологические проблемы качества подземных вод в настоящий момент являются одними из самых приоритетных в мире. Несмотря на значительные запасы подземных вод, население России вынуждено покупать очищенную воду. С точки зрения экологии человека, употребление очищенной воды не является положительным фактором для здоровья человека. Таким образом, люди не имеют доступа к чистой природной воде.

В этой связи, эколого-гидрогеологическая оценка качества подземных вод является актуальной задачей.

Целью данного исследования является экологогидрогеологическая оценка состояния подземных вод водоносного турон-коньякского карбонатного комплекса в районе села Старая Калитва Россошанского района Воронежской области.

Проводимые исследования необходимы для оценки состояния и обеспечения качества подземных вод, используемых для питьевого, и технического водоснабжения населения Старая Калитва Россошанского района Воронежской области. Время проведения работ с 2012 по 2019 г.

Для достижения поставленной цели были рассмотрены экологические функции водоносного турон-коньякского карбонатного комплекса в соответствии с [1]. В этом случае, задачи исследования были следующие:

1) ресурсная экологическая оценка подземных вод водоносного турон-коньякского карбонатного комплекса;

2) эколого-гидрогеохимическая оценка подземных вод водоносного турон-коньякского карбонатного комплекса;

3) эколого-геофизическая оценка подземных вод водоносного турон-коньякского карбонатного комплекса;

4) эколого-гидродинамическая оценка подземных вод водоносного турон-коньякского карбонатного комплекса;

5) разработка системы природоохранных мероприятий для обеспечения качества питьевых вод в районе села Старая Калитва Россошанского района Воронежской области.

Район исследований располагается в 2 км западнее села Старая Калитва Россошанского района
Воронежской области и относится к юго-восточной части Среднерусской возвышенности.

Наибольшая абсолютная высота достигает 211 м. Самые низкие абсолютные высоты приурочены к долинам рек Черная Калитва (70 м) и Дон (67 м). Рельеф образован сочетанием узких уплощенных водоразделов (средние абсолютные отметки 160-170 м) и глубоко врезанных широких балочных и речных долин, склоны которых осложнены большим количеством растущих оврагов [2].

Гидросеть района принадлежит к бассейну реки Дон. Основной водной артерией района является р. Дон и ее правый приток р. Черная Калитва.

Эколого-гидрогеологическая оценка состояния водоносного турон-коньякского карбонатного комплекса осуществлялась по результатам опробования 3$\mathrm{x}$ разведочно-эксплуатационных скважин, пробуренных для водоснабжения животноводческого комплекса. Нормативное водопотребление соответствует фактическому и не превышает 353.7 м³/сут (129.1 тыс. $\mathrm{M}^{3} /$ год).

Полевые гидрогеологические исследования проводились на существующих скважинах. Глубина каждой из трех скважин составляет 95 м. Расстояние между скважинами - 100-150 метров. Схема расположения скважин представлена на рис. 1 .

\section{Методика исследований}

Оценка состояния водоносного турон-коньякского карбонатного комплекса проводилась в соответствии с поставленными задачами:

1) ресурсная экологическая оценка водоносного турон-коньякского карбонатного комплекса производилась на основании расчета и анализа следующих параметров:

- литологии водовмещающих пород, мощности водоносного горизонта, глубины залегания подземных вод, положения статического уровня;

- размеров зон санитарной охраны подземных вод;

- бактериологических характеристик подземных вод [1];

- органолептических характеристик: запах, привкус цветность, мутность [1].

Литология водовмещающих пород, мощность водоносного комплекса, глубина залегания подземных вод, положение статического уровня определялись в 


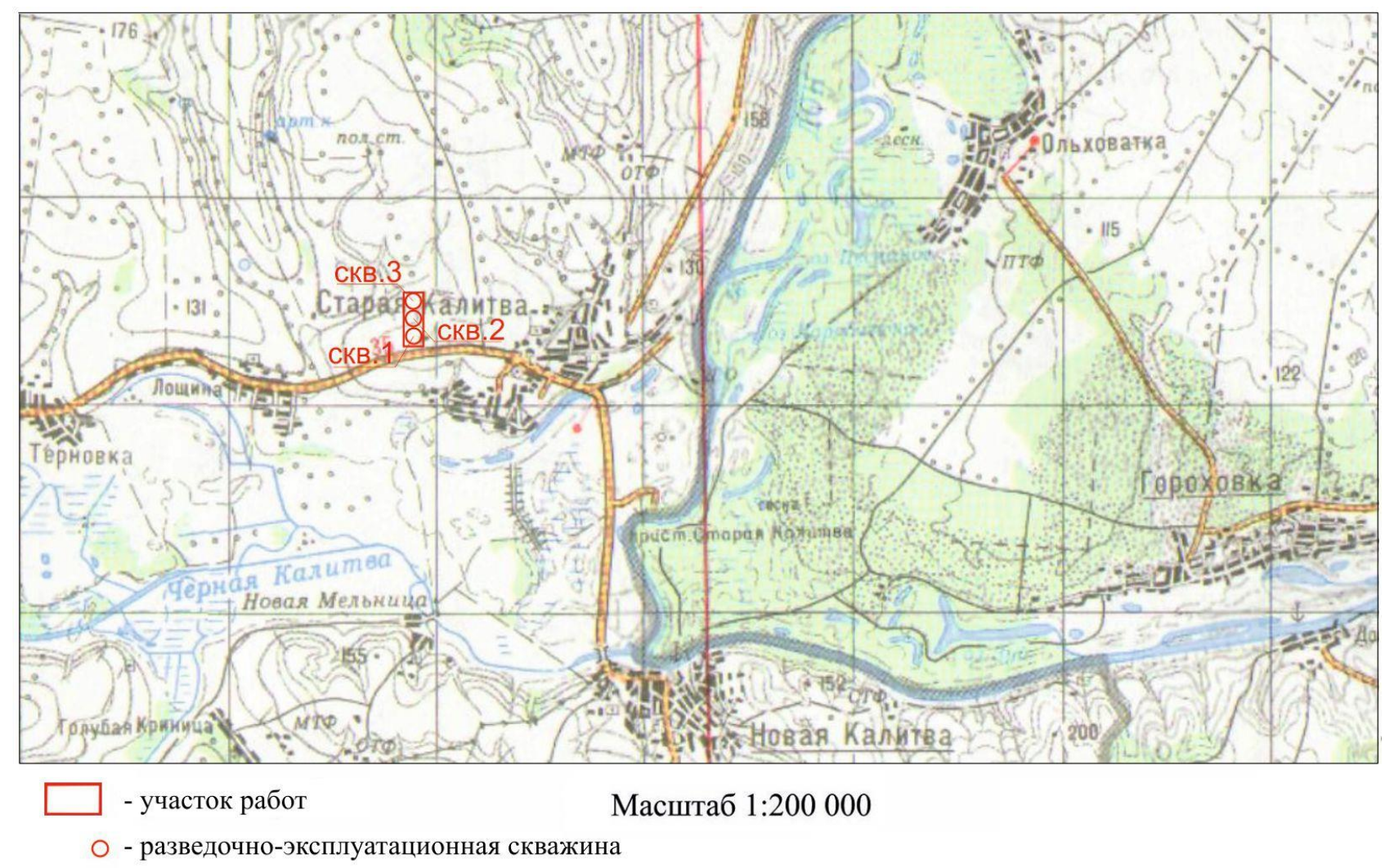

Рис. 1. Карта территории исследований и расположения разведочно-эксплуатационных скважин.

[Fig. 1. Map of the study area and location of exploration and production wells.]

результате проведения буровых работ, опытно-фильтрационных и мониторинговых работ.

Для обеспечения качества подземных вод, a, следовательно, и ресурса подземных вод, производилось определение размеров и контроль состояния зон санитарной охраны. Размер первого пояса ЗСО составляет 30 м для защищенных подземных вод. Удаление границ второго и третьего поясов зон санитарной охраны, предназначенных, соответственно, для защиты от микробного и химического загрязнения, рассчитывалось по формуле для каждой скважины (без учета бытового потока подземных вод):

$$
\mathrm{R}_{2}=\sqrt{\frac{Q \bullet T}{\pi \bullet \mu \bullet H}},
$$

где $\mathrm{R}$ - радиус санитарной охраны второго пояса, м; $\mathrm{Q}$ - дебит каждой проектируемой скважины $\mathrm{T}$ - расчетное время, сут Н - мощность водоносного комплекса, м.

$\mu$ - водоотдача или активная пористость водовмещающих пород.

Для анализа бактериологического состояния подземных вод водоносного турон-коньякского карбонатного комплекса с 2012 по 2019 г. производился мониторинг по следующим показателям: общие колиформные бактерии, термотолерантные колиформные бактерии, общее микробное число.

2) Эколого-гидрогеохимическая оценка водоносного турон-коньякского карбонатного комплекса приводилась на основании сравнения фактических концентраций веществ с предельно-допустимыми концентрациями (ПДК). Мониторинг за состоянием качества подземных вод осуществлялся с 2012 по 2019 г. Анализ производился по следующим показателям:

б) химическим: водородный показатель, сухой остаток, общая жесткость, перманганатная окисляемость, алюминий, бор, кадмий, кальций, марганец, мышьяк, никель, хлор, хром, цианиды, магний, свинец, сульфаты, фтор, ДДТ, 2.4-Д, железо, нитраты, нитриты, аммиак, цинк, ГХЦГ, медь, гидрокарбонаты, молибден.

Для оценки степени загрязненности подземных вод каждым загрязняющим веществом (табл. 1) был использован параметр, имеющий взаимосвязь с экологической обстановкой $[2,3,4,5]$. Этим параметром является:

Кк - коэффициент концентрации по каждому элементу, превышающему ПДК, который рассчитывается по формуле:

$$
K_{\mathrm{K}}=\frac{C_{i}}{C_{\text {пдк }}},
$$

где $C_{i}$ - концентрации элемента в анализируемой пробе (мг/дм $\left.{ }^{3}, \mathrm{мг} / к г\right)$;

$C_{\text {Пдк }}$ - нормируемая предельно допустимая концентрация данного элемента (мг/дм³, мг/кг).

Для комплексной (суммарной) оценки качества питьевых вод был использован суммарный показатель загрязнения (СПЗ), рассчитанный по формуле: 
Табл. 1. Нормирование состояния подземных вод по степени загрязнения

[Table 1. Normalization of groundwater by pollution]

\begin{tabular}{|c|c|c|}
\hline $\begin{array}{l}\text { Значения Кк веществ } 2 \text { класса опасности } \\
\text { Values of } \mathrm{C}_{\mathrm{C}} \text { substances of hazard class } 2\end{array}$ & $\begin{array}{l}\text { Значения Кк веществ } 3 \text { класса опасности } \\
\text { [Values of } \mathrm{C}_{\mathrm{C}} \text { substances of hazard class } 3 \text { ] }\end{array}$ & $\begin{array}{c}\text { Оценка состояния вод } \\
\text { [Water condition assessment] }\end{array}$ \\
\hline$<1$ & $<1$ & $\begin{array}{l}\text { Допустимое } \\
\text { [Allowable] }\end{array}$ \\
\hline $1-2$ & $1-5$ & $\begin{array}{c}\text { Умеренно опасное } \\
\text { [Moderately dangerous] }\end{array}$ \\
\hline $2-5$ & $5-10$ & $\begin{array}{c}\text { Oпасное } \\
\text { [Dangerous }]\end{array}$ \\
\hline $5-10$ & $10-15$ & $\begin{array}{c}\text { Высоко опасное } \\
\text { [Highly dangerous] }\end{array}$ \\
\hline$>10$ & $>15$ & $\begin{array}{l}\text { Чрезвычайно опасное } \\
\text { [Extremely dangerous] }\end{array}$ \\
\hline
\end{tabular}

$$
C \Pi 3=\sum_{1}^{\mathrm{n}} K_{\mathrm{K}_{\mathrm{n}}}-(\mathrm{n}-1) ;
$$

$K \kappa_{\mathrm{n}}-$ коэффициент концентрации по каждому элементу, превышающему ПДК;

$\mathrm{n}$ - количество элементов, по которым отмечается превышение ПДК.

Для анализа динамики загрязнения подземных вод были использованы средние показатели концентрации загрязняющих веществ и средние значения СПЗ, а для оценки степени загрязнения и качества воды использовались максимальные концентрации загрязняющих веществ и максимальное значение СПЗ.

3) Эколого-геофизическая оценка подземных вод производилась по следующим показателям: удельная суммарная $\alpha$-активность, удельная суммарная $\beta$ активность, удельная активность радона- 222 .

4) Эколого-гидродинамическая оценка водоносного турон-коньякского карбонатного комплекса производилась на основании расчета следующих гидродинамических показателей: расчетной величины водопотребления, удельного дебита скважин, приведенного радиуса влияния скважин, коэффициента водопроводимости, коэффициента уровнепроводности, расчета обеспеченности запасов подземных вод на срок эксплуатации водозабора (25 лет) и расчета максимального дебита при условии сохранения существующей системы водоснабжения. Обеспеченность запасов эксплуатируемого водоносного горизонта оценивалась путем расчета понижения уровня подземных вод в процессе эксплуатации водозабора и сравнении полученного значения с допустимым.

Оценка эколого-гидродинамических условий производилась на основе определения максимально допустимого водоотбора при существующей системе расположения скважин, на расчетный срок его эксплуатации $10^{4}$ суток.

Водозабор состоит из трех эксплуатационных скважин, расположенных в линейном ряду $(l=350$ м). Для расчётов они были заменены обобщённой системой («большим колодцем»).

Расчётное понижение уровня в центре обобщённой системы будет слагаться из понижения уровня в скважине и зависеть от вида системы и граничных условий продуктивного комплекса $-\mathrm{S}_{\text {об̆ }}$ a также от величины дополнительного понижения в той же скважине, которое зависет от расположения скважин внутри системы, их несовершенства и расхода каждой известнякних $-\mathrm{S}_{\mathrm{c \kappa}}[6,7]$.

$$
\mathrm{S}_{\mathrm{pacч}}=\mathrm{S}_{\text {об }}+\mathrm{S}_{\mathrm{c \kappa}}
$$

Так как эксплуатация водозабора будет производиться длительное время ( $\approx 10^{4}$ суток), аналитические расчёты можно выполнить по формуле для условий квазистационарного режима фильтрации, если на водозаборных участках все взаимодействующие скважины были введены в эксплуатацию одновременно.

При этих условиях понижение уровня в скважине $\left(\mathrm{S}_{\text {об}}\right)$ можно определить по следующему уравнению:

$$
S_{\text {об }}=\frac{Q_{c y м}}{4 \pi k m} R_{\text {об }},
$$

где $R_{\text {об }}$ - внешнее фильтрационное сопротивление, вызываемое действием обобщенной системы.

$$
R_{\text {об }}=\ln \frac{2.25 a t}{r_{k}^{2}},
$$

где $r_{k}=0.2 l$. (7)

Величину дополнительного сопротивления $-\mathrm{S}_{\mathrm{ck}}$ можно определить по формуле:

$$
S_{c \kappa}=\frac{Q_{i}}{4 \pi k m} \Delta R_{c \kappa s},
$$

где $\Delta R_{\text {скв }}$ - дополнительное сопротивление, зависящее от расположения скважин внутри системы и их несовершенства (так называемое внутреннее сопротивление).

$$
\Delta R_{\text {скв }}=2\left(\ln \frac{r_{n p}}{r_{\text {скв }}}+\xi\right),
$$

где $r_{n p}$ - приведенный радиус влияния данной скважины внутри обобщающей системы, $\xi$ - гидравлическое сопротивление, вызываемое несовершенством данной скважины [7].

$$
r_{n p}=\frac{a+b}{2 \pi}
$$

где $a, b$ - половина расстояния между скважинами. 
Гидродинамический потенциал водоносного турон-коньякского карбонатного комплекса оценивается по формуле:

$$
Q_{c y M}=\frac{12 S_{o \sigma} \pi k m}{3 \ln \frac{2.25 a t}{r_{k}^{2}}+2\left(\ln \frac{r_{n p}}{r_{\text {скв }}}+\xi\right)}
$$

\section{Результаты исследований}

Ресурсная экологическая оценка подземных вод водоносного туронконьякского карбонатного комплекса

В пределах рассматриваемого участка геологический разрез сложен осадочными породами мела и четвертичной системы $[8,9]$.

\section{Меловая система}

Отложения мелового возраста со стратиграфическим перерывом и угловым несогласием залегают на породах девона и карбона. Их подошва очень полого погружается на юго-запад и на участке работ представлены верхним отделом.

\section{Верхний отдел}

Верхний мел трансгрессивно залегает на подстилающих отложениях и представлен туронским, коньякским, сантонским и кампанским ярусами.

\section{Туронский ярус}

Tускаръская свита $\left(K_{2} t s\right)$, сопоставляющаяся с туронским ярусом, развита почти на всей территории района. В нижней части разреза тускарьские отложения представлены мелом серовато-белым, песчаным с галькой и желваками фосфоритов. Вверх по разрезу мел постепенно становится более чистым, в нем отмечаются следы илоедов. Мощность тускарьской свиты увеличивается от 20 м на северо-востоке до 60 м на юго-западе.

\section{Коньякский ярус}

Чернянская свита $\left(K_{2} \check{c} r\right)$ залегает согласно с подстилающими отложениями. Представлена белым писчим мелом с прослоями (до 2 м) светло-серого глинистого мела. Мощность чернянской свиты изменяется в пределах 12-35 м.

\section{Сантонский ярус}

Истобненская свита (K $\left.K_{2} i s\right)$ залегает со следами размыва на чернянской свите и представлена белым писчим мелом с прослоями мелоподобного мергеля. Мощность - 20-35 м.

Подгорненская толща $\left(K_{2} p d\right)$ представлена переслаивающимися глинистыми и мело-подобными мергелями общей мощностью 50 м.

\section{Неогеновая система}

Представлена озерными отложениями белогорской свиты плиоцена.

\section{Плиоцен}

Белогорская свита $\left(N_{2} b g\right)$ образует самую низкую неогеновую террасу, подошва аллювия которой располагается на абсолютных отметках около 100 м. Ее отложения общей мощностью до 15 м представлены кварцевыми разнозернистыми, глинистыми песками, которые вверх по разрезу сменяются глинами и суглинками. Они распространены по левому борту долины Черной Калитвы, а также по левобережью Россоши. Ширина террасы достигает 3-4 км.

\section{Четвертичная система}

На территории района четвертичные отложения распространены почти повсеместно, отсутствуя только на обрывистых участках и крутых склонах долин. Они плащеобразно перекрывают водоразделы, склоны речных долин и балок, выстилают днища долин и слагают террасы; представлены аллювиальными и субаэральными отложениями.

\section{Неоплейстоцен}

Нижнее звено

Криоэлювиальные отложения (L I)

Распространены на правом и левом бортах долины p. Черная Калитва, покрывают плащом склоны и сниженные водоразделы, достигают мощности 14-16 м и представлены тремя основными типами разрезов.

Мучкапский, окский и лихвинский горизонтьл

Мучкапско-лихвинские аллювиальные отложения (aImc-II lh) залегают в виде трех констративно наслоенных друг на друга аллювиальных пачек (обычно под аллювием четвертой надпойменной террасы, слагая ее цоколь). Подошва отложении в долине реки Черная Калитва находится на отметках 90-105 м, мощность их составляет обычно 8-12 м, максимум 16 м.

Нижняя пачка - это нормальный русловой аллювий, с гравием местных и дальнеприносных пород (шокшинских песчаников, полевых шпатов).

Средняя пачка сложена тонкозернистыми песками с тонкой горизонтальной и наклонной слоистостью (имеет характер перигляциального аллювия).

Верхняя пачка - русловой аллювий (косослоистые пески с линзами галечников) характеризуется очень неустойчивым гранулометрическим составом, скачкообразно изменяющимся по разрезу.

Участок работ находится в пределах ДонецкоДонского артезианского бассейна, где основным эксплуатационным водоносным горизонтом является турон-коньякский водоносный комплекс.

На территории исследования верхнечетвертичный терригенный горизонт сдренирован.

Водоносный турон-коньякский карбонатный ком$n л е к с-K_{2} t-k$ приурочен к зоне трещиноватых обводненных пород туронского и коньякского ярусов верхнего мела. Водовмещающими породами служат мела, степень трещиноватости которых весьма неравномерна. Глубина залегания кровли водовмещающих пород изменяется от долей метра в долинах рек до 30-120 м 
на водоразделах. Комплекс безнапорный, и только на поймах рек в южной части района местами отмечается напор до 18 м. Нижний водоупор отсутствует. Мощность обводненной толщи, в среднем, составляет 50 м. Коэффициент фильтрации водовмещающих пород от 0.1 до 39 м/сут, на участке работ 1.5-2.0 м/сут. Направление движения подземных вод с северовостока на юго-запад, от водораздела в долину $\mathrm{p}$. Черная Калитва. В районе исследований, комплекс эксплуатируется тремя скважинами, расположенными на расстоянии 100-150 м друг от друга. Глубины скважин - 95 м. Статический уровень устанавливается на глубине 56-60 м (а.о.69-65м). Комплекс безнапорный.

Водообильность скважин в период строительной откачки составляла 2.4-2.8 л/с, при понижении уровня 22-25 м, удельные расходы $0.1-0.13$ л/с.

По химическому составу воды турон-коньякского водоносного горизонта пресные, с минерализацией до 3.2 г/л, общей жесткостью 12.5 мг-экв/дм³

Удаление границ второго пояса зоны санитарной охраны для каждой скважины, предназначенного для защиты от микробного загрязнения, рассчитывается по формуле 1, где:

$\mathrm{R}$ - радиус санитарной охраны второго пояса, м;

$\mathrm{Q}$ - дебит каждой проектируемой скважины 117.9 $\mathrm{M}^{3} /$ сут;

$\mathrm{T}$ - время продвижения микробного загрязнения воды, сут. (200 сут.);

$\mathrm{H}$ - мощность водоносного горизонта, м. (20.0 м); $\mu$ - водоотдача или активная пористость водовмещаю- щих пород (для мелов - 0.05) [7].

Подставляя в формулу 1 числовые значения, входящих в нее параметров, получим:

$$
\mathrm{R}_{2}=\sqrt{\frac{117.9 \cdot 200}{3.14 \bullet 0.05 \cdot 20.0}}=86.7 \mathrm{M}
$$

Следовательно, радиус зоны санитарной охраны второго пояса по скважинам равен 86.7 м.

Удаление границ третьего пояса зоны рассчитывается по той же формуле 1, но значение времени возможного химического загрязнения принимается равным 25 лет или 10000 суток, т.е.

$$
\mathrm{R}_{3}=\sqrt{\frac{353.7 \cdot 10000}{3.14 \bullet 0.05 \bullet 20.0}}=1061.3 \mathrm{M}
$$

Следовательно, радиус зоны санитарной охраны третьего пояса по скважинам равен 1061.3 м.

В границах, обозначенных $3 \mathrm{CO}$ источники загрязнения подземных вод представлены автодорогой, а также животноводческим комплексом. Объектов, оказывающих негативное воздействие на состояние водоносного турон-коньякского карбонатного комплекса в границах 3-его пояса $3 \mathrm{CO}$ не выявлено. На рис. 2 отображены границы 3СО 2 и 3 поясов, а на рис. 3 гидрогеологический разрез по линии I-I.

В результате проведения бактериологического анализа выявлено отсутствие общих колиформных бактерий и термотолерантных колиформных бактерий. Общее микробное число варьирует от 0 до 3, что соответствует нормативам $[10,11]$.

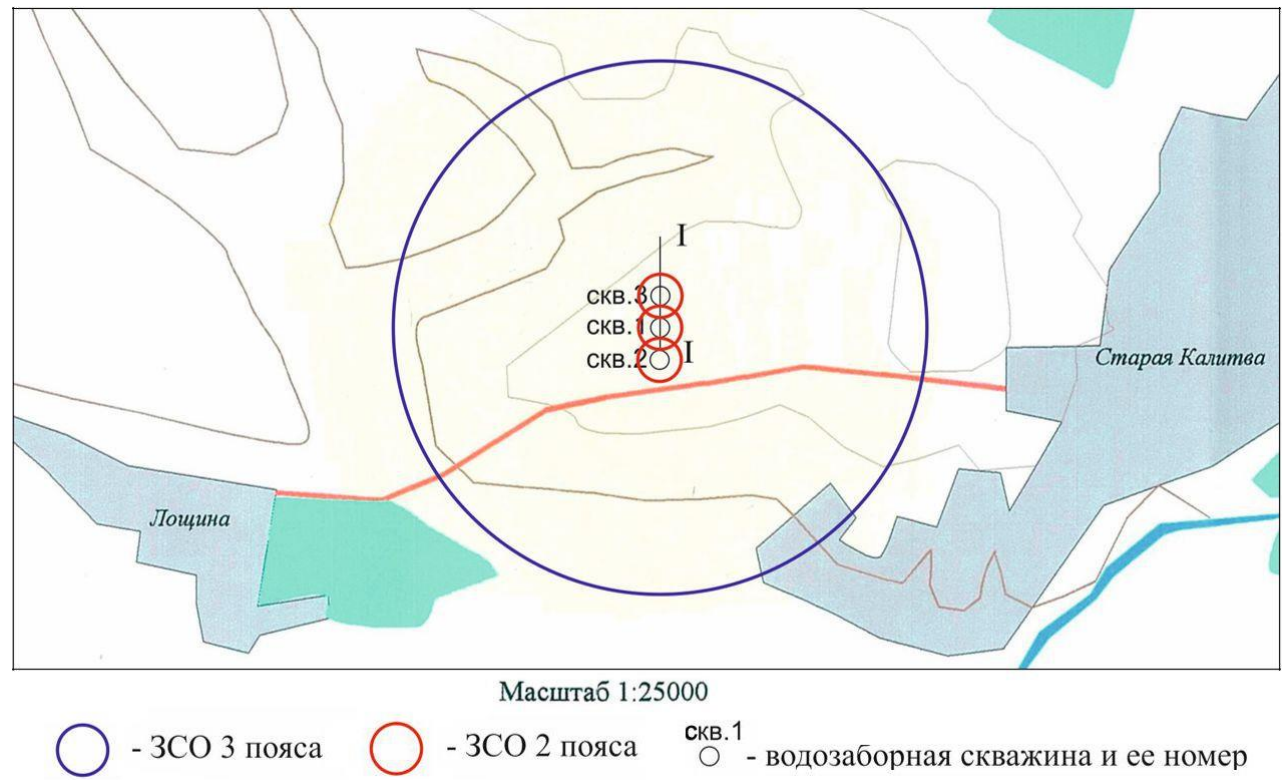

Рис. 2. Границы зон санитарной охраны

[Fig. 2. The boundaries of the sanitary protection zones]

\section{Эколого-гидрогеохимическая оченка подземных вод водоносного}

турон-коньякского карбонатного комплекса

С начала мониторинговых наблюдений и по настоящее время химический состав вод был непостоянным.
Величина сухого остатка изменялась от 562 до 3208 мг/дм ${ }^{3}, \mathrm{pH}-6.1-7.85$. Жёсткость изменялась в пределах 9.1-30.7 мг/дм ${ }^{3}$ (очень жесткие воды), концентрация железа общего - <0.19-3.20 мг/дм³ ${ }^{3}$ Содержание хлоридов - 170.3-1397.2 мг/дм³ , сульфатов - 140.9 
Масштаб 1:25000

Масштаб: вертикальный 1:1000

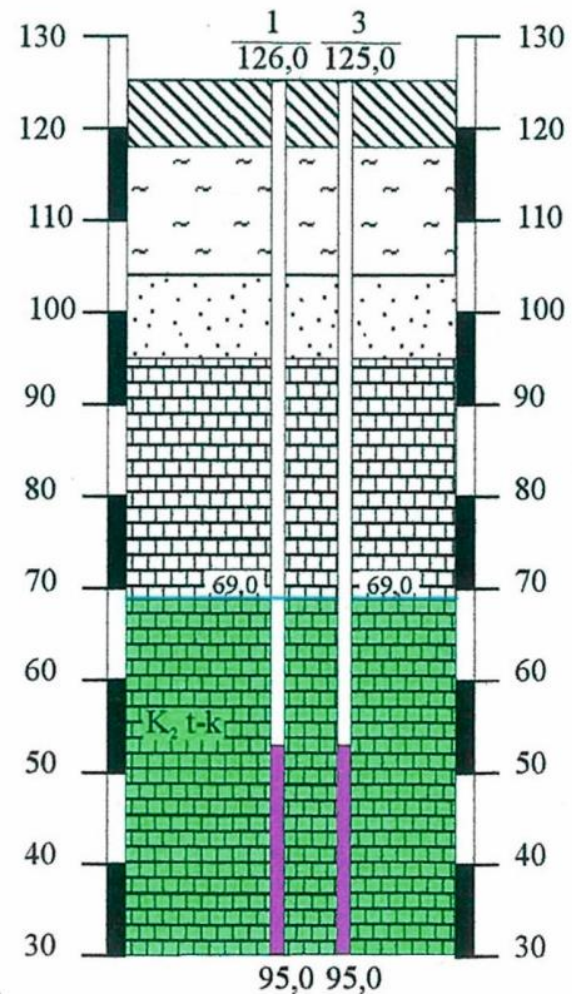

Гидрогеологические подразделения:

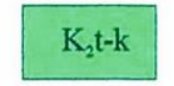

Водоносный турон-коньякский карбонатный комплекс. Мел, мергель.

Статический уровень турон-коньякского карбонатного комплекса.

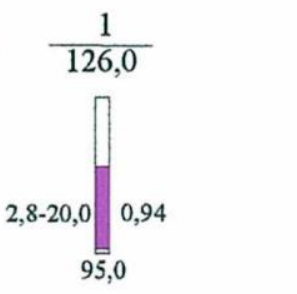

Химический состав подземньх вод:

Трехкомпонентный

Литологический состав пород

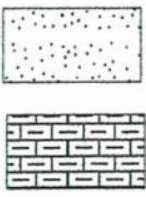

Рис.3. Гидрогеологический разрез линии I-I

[Fig. 3. Hydrogeological section of line I-I]

445.8 мг/дм³ ${ }^{3}$ Компоненты азотной группы - нитраты (0.15-12.3 мг/дм $\left.{ }^{3}\right)$, соли аммония, нитриты - в норме [10]. Величина окисляемости изменяется от $<0.25$ до $4.4 \mathrm{мг} /$ дм $^{3}$, в норме [10]. Из микрокомпонентов: фтор -

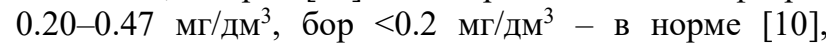
марганец - $<0.1$ мг/дм ${ }^{3}-$ в норме [10]. Другие микрокомпоненты (алюминий, медь, молибден, цинк, свинец и т.д.) присутствуют в макроколичествах [10]. По результатам лабораторных работ установлено, что значительных изменений химического состава подземных вод за 7 лет не наблюдается. По результатам эколого-гидрогеохимической оценки состояния подземных вод отмечается превышение мутности, концентраций железа, хлоридов, магния, повышенное содержание сухого остатка и общей жесткости.

Подземные воды турон-коньякского карбонатного комплекса по анионному составу гидрокарбонатносульфатно-хлоридные, пор катионному - магниевокальциевые (рис. 4).

Результаты химического анализа подземных вод приведены в таблице 2.

По основным загрязняющим веществам были построены графики динамики их концентраций. Средние концентрации сухого остатка достигают 1796 мг/дм³. Отмечается ежегодное превышение средних значений сухого остатка (рис. 5).

По средним величинам общей жесткости подземные воды характеризуются как очень жесткие (макси-
Пески

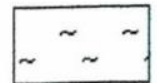

Глины

Мергель

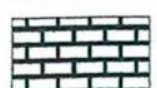

Мел
Сважина гидрогеологическая.

вверху - номер по карте и абсолютная скважины. Закраска соответствует типу воды в опробованном интервале глубин. Цифры слева от интервала опробования: первая - дебит л/сек, вторая - понижение, м; справа - минерализация воды, $\mathrm{r} /$ дм$^{3}$.

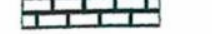

Рис. 4. Диаграмма химического состава подземных вод водоносного турон-коньякского карбонатного комплекса. [Fig. 4. Diagram of the chemical composition of groundwater in the aquifer of the Turonian-Cognac carbonate complex.]

мальное значение - 16.4 мг-экв/л) (рис. 6).

Средняя концентрация железа варьируют в пределах $0.22-1.42$ мг/дм ${ }^{3}$ (рис.7). Максимальные концентрации отмечаются в 2018 г., а минимальные - в 2014 г. 
Табл. 2. Качество подземных вод водоносного турон-коньякского карбонатного комплекса [Table 2. Groundwater quality of the aquifer Turonian-Cognac carbonate complex]

\begin{tabular}{|c|c|c|c|c|}
\hline № & $\begin{array}{c}\text { Наименование } \\
\text { Показателей } \\
\text { [Name } \\
\text { Indicators] }\end{array}$ & $\begin{array}{c}\text { Единица } \\
\text { измерения } \\
\text { [Unit } \\
\text { measuring] }\end{array}$ & $\begin{array}{c}\text { Нормативное } \\
\text { содержание } \\
\text { (ПДК) } \\
\text { [Regulatory } \\
\text { Content (MPC)] }\end{array}$ & $\begin{array}{c}\text { Фактическое содержание в } \\
\text { скважинах 1-3 } \\
\frac{\text { от - до }}{\text { среднеe }} \\
\text { [Actual content in wells 1-3 } \\
\text { from - to } \\
\text { average } \\
\end{array}$ \\
\hline 1 & 2 & 3 & 4 & 5 \\
\hline 1 & $\mathrm{pH}$ & $\begin{array}{l}\text { единицы pH } \\
\text { [pH units] }\end{array}$ & $6-9$ & $\frac{6.1-7.85}{7.13}$ \\
\hline 2 & $\begin{array}{c}\text { 3aпax } \\
{[\text { Smell }]}\end{array}$ & $\begin{array}{c}\text { балл } \\
\text { [point] }\end{array}$ & 2 & $\frac{0-2}{0.3}$ \\
\hline & $\begin{array}{l}\text { Привкус } \\
\text { [Smack] }\end{array}$ & $\begin{array}{c}\text { балл } \\
\text { [point] }\end{array}$ & 2 & $\frac{0-2}{0.3}$ \\
\hline 3 & $\begin{array}{l}\text { Цветность } \\
\text { [Color] }\end{array}$ & $\begin{array}{l}\text { градусы } \\
\text { [degrees] }\end{array}$ & 20 & $\frac{1-15.5}{6.4}$ \\
\hline 4 & $\begin{array}{l}\text { Мутность } \\
\text { [Turbidity] }\end{array}$ & $\begin{array}{c}\mathrm{M} \Gamma / \mathrm{дm}^{3} \\
{\left[\mathrm{mg} / \mathrm{dm}^{3}\right]}\end{array}$ & 1.5 & $\frac{0.6-24.9}{2.36}$ \\
\hline 5 & $\begin{array}{c}\text { Сухой остаток } \\
\text { [Solids concentration] }\end{array}$ & $\begin{array}{c}\mathrm{M \Gamma} / \mathrm{AM}^{3} \\
{\left[\mathrm{mg} / \mathrm{dm}^{3}\right]}\end{array}$ & 1000 & $\frac{562-3208}{1239.9}$ \\
\hline 6 & $\begin{array}{l}\text { Общая жесткость } \\
\text { [Total hardness] }\end{array}$ & $\begin{array}{l}\mathrm{M \Gamma -эКв/л} \\
{[\mathrm{mEq} / 1]}\end{array}$ & 7 & $\frac{9.1-30.7}{12.48}$ \\
\hline 7 & $\begin{array}{c}\text { Перманганатная окисляемость } \\
\text { [Permanganate oxidizability] }\end{array}$ & \multirow{14}{*}{$\begin{array}{c}\text { мг/ дм }{ }^{3} \\
{\left[\mathrm{mg} / \mathrm{dm}^{3}\right]}\end{array}$} & 5.0 & $\frac{0.25-4.4}{1.49}$ \\
\hline 8 & $\mathrm{Al}$ & & 0.2 & $<0.04$ \\
\hline 9 & $\mathrm{~B}$ & & 0.5 & $<0.2$ \\
\hline 10 & $\mathrm{Cd}$ & & 0.001 & $\frac{0.0001-0.0008}{0.00014}$ \\
\hline 11 & $\mathrm{Ca}$ & & - & $\frac{144.3-460.9}{159.6}$ \\
\hline 12 & $\mathrm{Mn}$ & & 0.1 & $<0.1$ \\
\hline 13 & As & & 0.01 & 0.001 \\
\hline 14 & $\mathrm{Ni}$ & & 0.02 & $\frac{<0.01-0.005}{0.0075}$ \\
\hline 15 & $\mathrm{Cl}$ & & 350.0 & $\frac{170.3-1397.2}{325.17}$ \\
\hline 16 & $\mathrm{Cr}$ & & 0.05 & $<0.025$ \\
\hline 17 & $\begin{array}{c}\text { Цианиды } \\
\text { [Cyanides] }\end{array}$ & & 0.07 & $<0.01$ \\
\hline 18 & $\mathrm{Mg}$ & & 50 & $\frac{25.5-81.4}{33.35}$ \\
\hline 19 & $\mathrm{~Pb}$ & & 0.01 & $\frac{0.0001-0.0074}{0.0007}$ \\
\hline 20 & $\mathrm{SO}_{4}$ & & 500.0 & $\frac{140.9-445.8}{270.72}$ \\
\hline 21 & $\mathrm{~F}$ & \multirow{11}{*}{$\begin{array}{c}\mathrm{M \Gamma} / \mathrm{дм}^{3} \\
{\left[\mathrm{mg} / \mathrm{dm}^{3}\right]}\end{array}$} & 1.5 & $\frac{0.20-0.47}{0.31}$ \\
\hline 22 & $\mathrm{C}_{14} \mathrm{H}_{9} \mathrm{C}_{15}$ & & 0.002 & $<0.0001$ \\
\hline 23 & $\mathrm{C}_{8} \mathrm{H}_{6} \mathrm{Cl}_{2} \mathrm{O}_{3}$ & & 0.03 & $<0.01$ \\
\hline 24 & $\mathrm{Fe}$ & & 0.3 & $\frac{0.19-3.20}{0.67}$ \\
\hline 25 & $\mathrm{NO}_{3}$ & & 45.0 & $\frac{0.15-12.3}{2.34}$ \\
\hline 26 & $\mathrm{NO}_{2}$ & & 3.0 & $\frac{0.003-0.09}{0.014}$ \\
\hline 27 & $\mathrm{NH}_{4}$ & & 2.0 & $\frac{0.04-0.75}{0.12}$ \\
\hline 28 & $\mathrm{Zn}$ & & 1.0 & $\frac{0.0005-0.056}{0.006}$ \\
\hline 29 & $\mathrm{C}_{6} \mathrm{H}_{6} \mathrm{Cl}_{6}$ & & 0.002 & $<0.0001$ \\
\hline 30 & $\mathrm{Cu}$ & & 1.0 & $\frac{0.005-0.086}{0.01}$ \\
\hline 31 & $\mathrm{HCO}_{3}$ & & - & $\frac{248.3-322.2}{300.42}$ \\
\hline
\end{tabular}


Продолжение Табл. 2

[Continued Table 2]

\begin{tabular}{|c|c|c|c|c|}
\hline 1 & 2 & 3 & 4 & 5 \\
\hline 32 & Mo & $\begin{array}{c}\mathrm{мг} / \mathrm{дм}^{3} \\
{\left[\mathrm{mg} / \mathrm{dm}^{3}\right]}\end{array}$ & 0.07 & $<0.01$ \\
\hline 33 & $\begin{array}{c}\text { a-активность } \\
\text { [a-activity] }\end{array}$ & \multirow{3}{*}{$\begin{array}{c}\text { Бк/л } \\
{[\mathrm{Bq} / 1]}\end{array}$} & 0.2 & $\frac{0.09-0.11}{0.1}$ \\
\hline 34 & $\begin{array}{c}\beta \text {-активность } \\
{[\beta \text {-activity }]}\end{array}$ & & 1.0 & $\frac{0.15-0.17}{0.16}$ \\
\hline 35 & $\begin{array}{c}\text { Радон } \\
\text { [Radon] }\end{array}$ & & 60.0 & $\frac{6.9-7.9}{7.3}$ \\
\hline 36 & $\begin{array}{l}\text { Общие колиформные бактерии } \\
\text { [Common coliform bacteria] }\end{array}$ & $\begin{array}{l}\text { Число бактерий в } 100 \text { мл } \\
\text { [the number } \\
\text { bacteria in } 100 \mathrm{ml}]\end{array}$ & 0 & 0 \\
\hline 37 & $\begin{array}{l}\text { Термотолерантные колиформные } \\
\text { бактерии } \\
\text { [Thermo-tolerant coliform bacteria] }\end{array}$ & $\begin{array}{c}\text { Число бактерий в } 100 \text { мл } \\
\text { [the number } \\
\text { bacteria in } 100 \mathrm{ml}]\end{array}$ & 0 & 0 \\
\hline 38 & $\begin{array}{l}\text { Общее микробное число } \\
\text { [Total microbial number] }\end{array}$ & $\begin{array}{c}\text { число образующих } \\
\text { колоний бактерий в } 1 \text { мл } \\
\text { [the number of forming } \\
\text { colonies of bacteria in } 1 \mathrm{ml}]\end{array}$ & $\begin{array}{c}\text { не более } 50 \\
\text { [no more than 50] }\end{array}$ & $\frac{0-3}{1.71}$ \\
\hline
\end{tabular}

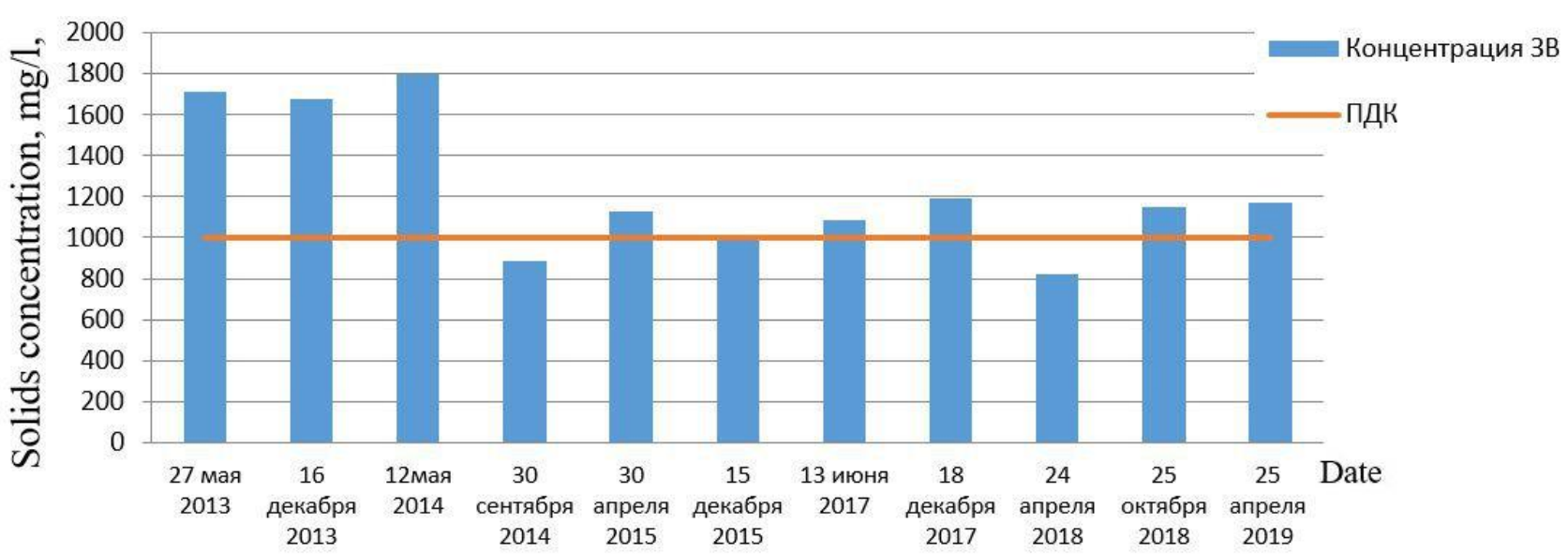

Рис. 5. Динамика средних концентраций сухого остатка в подземных водах водоносного турон-коньякского карбонатного комплекса.

[Fig. 5. Dynamics of average concentrations of solids in groundwater of the aquifer Turonian-cognac carbonate complex.]

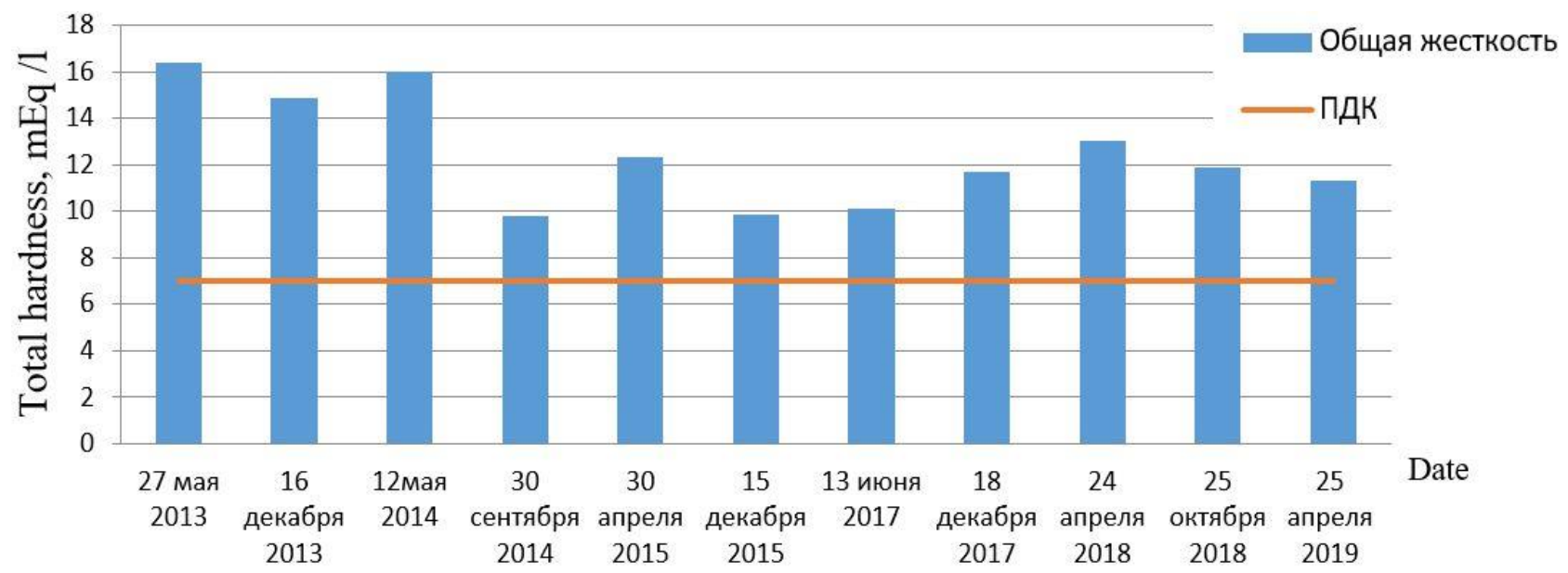

Рис. 6. Динамика средних значений общей жесткости в подземных водах водоносного турон-коньякского карбонатного комплекса.

[Fig. 6. Dynamics of average values of total hardness in groundwater of the aquifer Turonian-cognac carbonate complex.] 


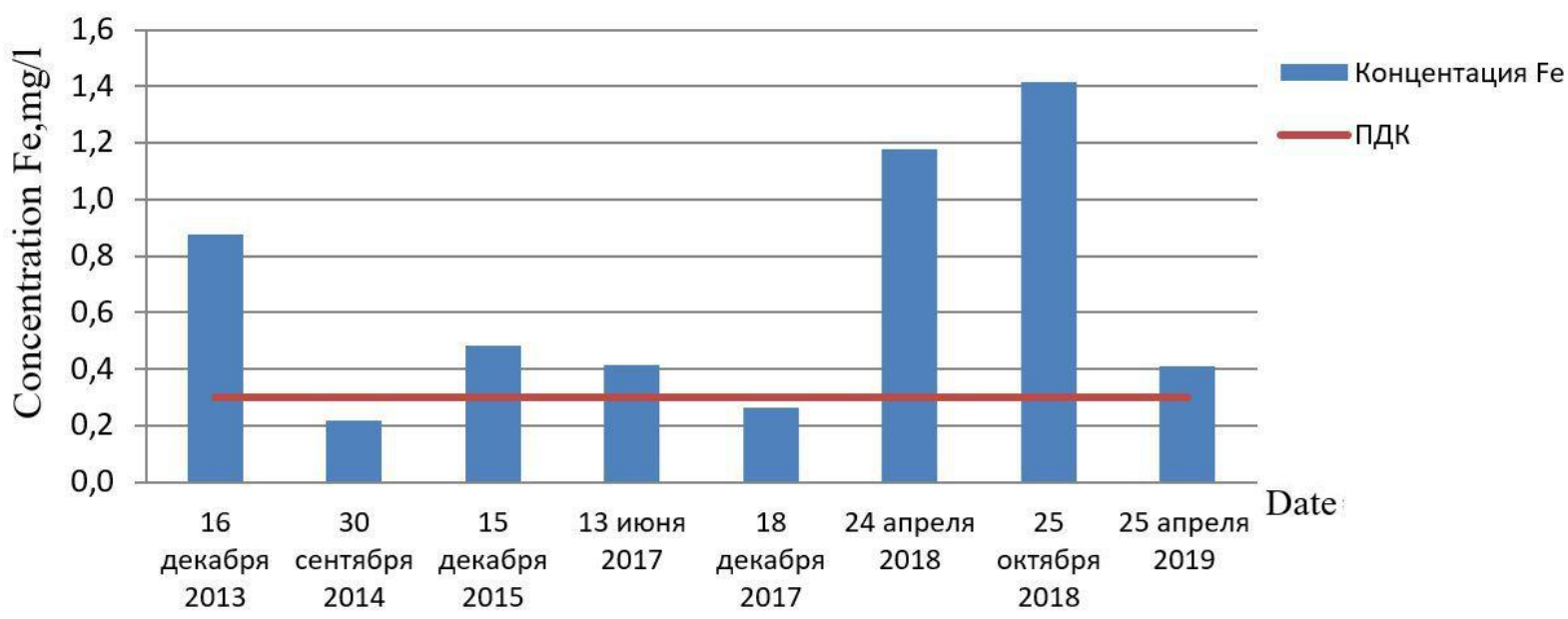

Рис. 7. Динамика средних концентраций железа в подземных водах водоносного турон-коньякского карбонатного комплекса.

[Fig. 7. Dynamics of average iron concentrations in the groundwater of the aquifer Turonian-Cognac carbonate complex.]

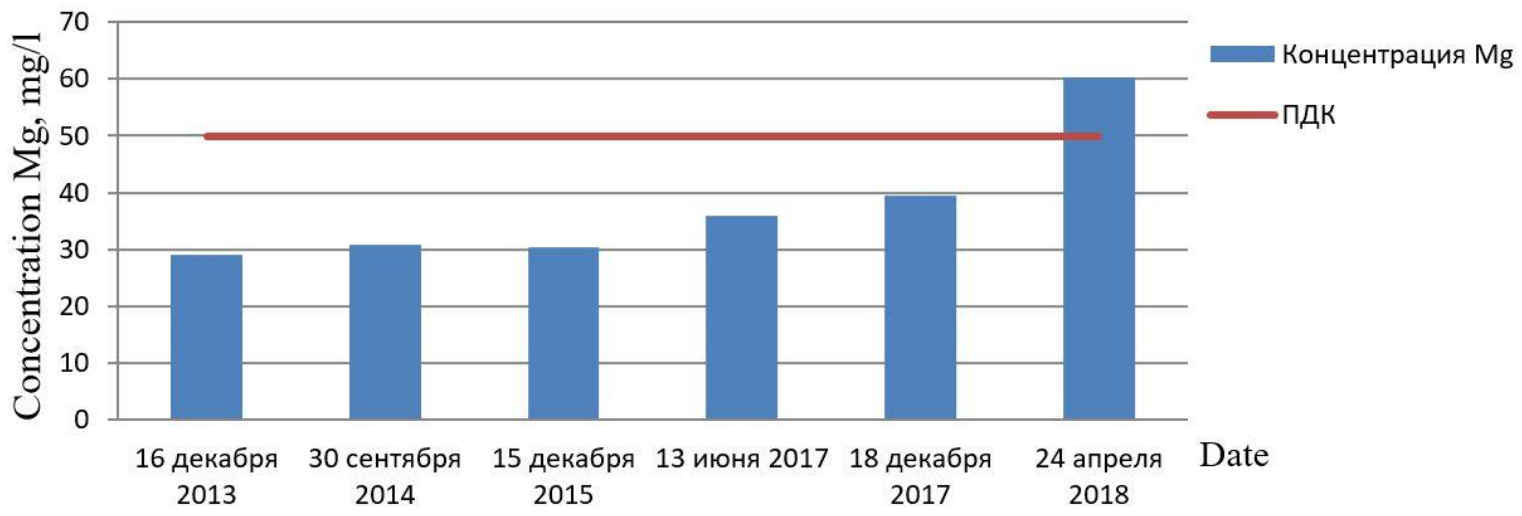

Рис. 8. Динамика средних концентраций магния в подземных водах водоносного турон-коньякского карбонатного комплекса.

[Fig. 8. Dynamics of average magnesium concentrations in the groundwater of the aquifer Turonian-cognac carbonate complex.]

Средняя концентрация магния варьирует от 29.1 мг/дм ${ }^{3}$ до 60.3 мг/дм³ (рис.8). Максимальные концентрации магния зафиксированы в 2018 г., а минимальные в 2013 г. Отмечается увеличение концентрации магния в процессе эксплуатации водозабора.
Средняя концентрация хлоридов варьирует от 231 мг/дм ${ }^{3}$ до 599.1 мг/дм³ (рис. 9). Максимальные концентрации отмечаются в 2013 году, а минимальные - в 2014 г. Средние концентрации хлоридов с 2014 по 2019 г. не превышали ПДК.

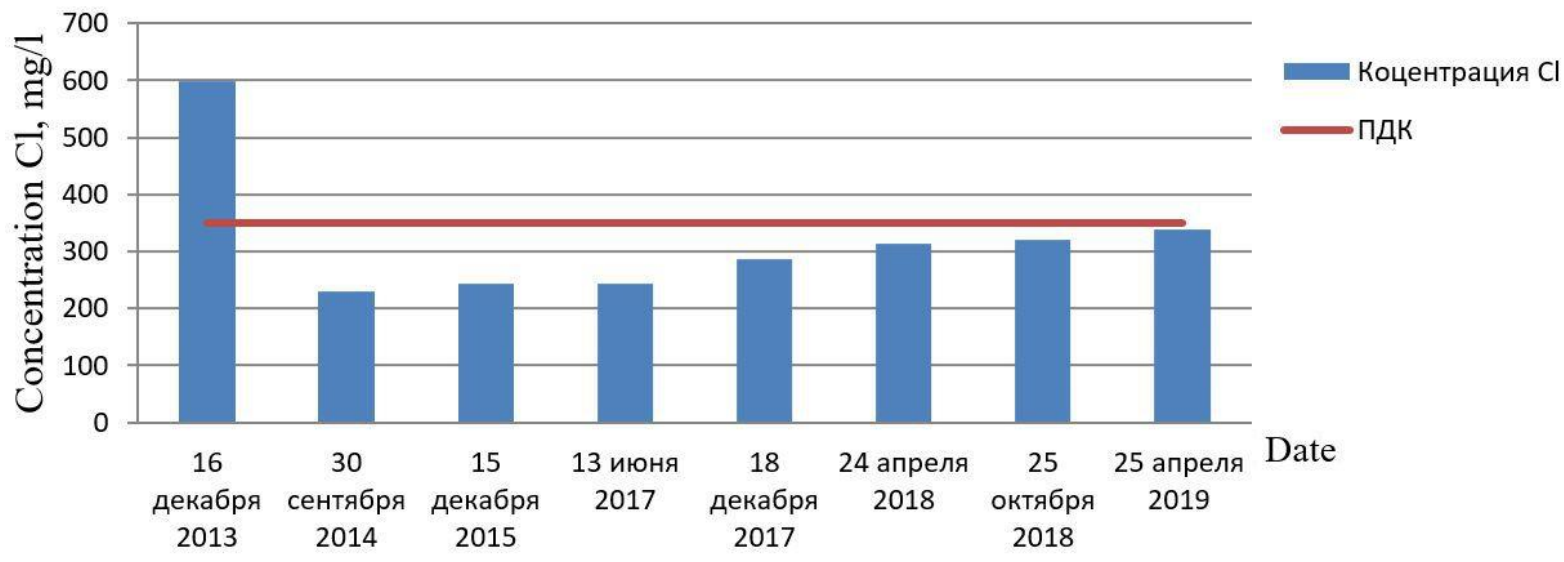

Рис. 9. Динамика средних концентраций хлоридов в подземных водах водоносного турон-коньякского карбонатного комплекса.

[Fig. 9. Dynamics of average chloride concentrations in the groundwater of the aquifer Turonian-cognac carbonate complex.] 


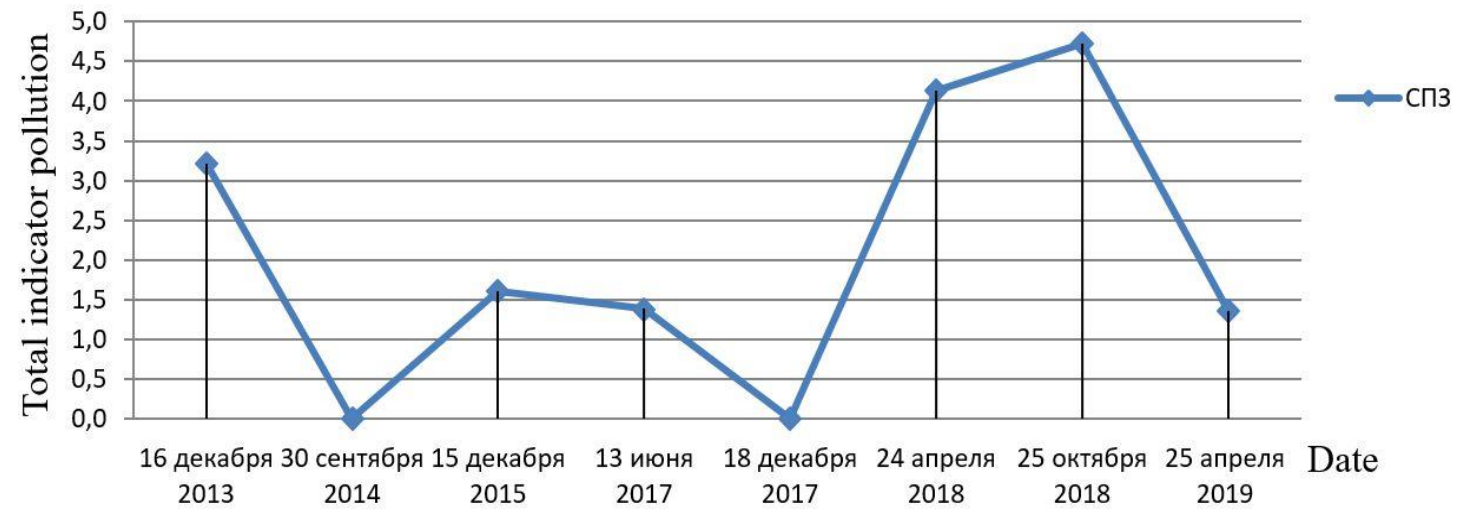

Рис. 10. Динамика средних значений суммарного показателя загрязнения водоносного турон-коньякского карбонатного комплекса.

[Fig. 10. Dynamics of average values of the total pollution indicator of the aquifer Turonian-Cognac carbonate complex.]

Табл. 3. Экологическая оценка загрязнения водоносного турон-коньякского карбонатного комплекса [Table 3. Ecological assessment of pollution of the aquifer Turonian-cognac carbonate complex]

\begin{tabular}{|c|c|c|c|}
\hline $\begin{array}{c}\text { Наименование показателей } \\
\text { [Name Indicators] }\end{array}$ & $\begin{array}{c}\text { Класс опасности } \\
\text { [Hazard Class] }\end{array}$ & $\begin{array}{c}\text { Концентрация, мг/дм } \\
\text { [Concentration, } \mathrm{mg} / \mathrm{dm}^{3} \text { ] }\end{array}$ & $\begin{array}{c}\text { Доли ПДК } \\
\text { [MPC units] }\end{array}$ \\
\hline $\begin{array}{c}\text { Мутность } \\
\text { [Turbidity] }\end{array}$ & - & 24.9 & 16.6 \\
\hline $\begin{array}{c}\text { Сухой остаток } \\
\text { [Solids concentration] }\end{array}$ & - & 3208 & 3.208 \\
\hline $\begin{array}{c}\text { Общая жесткость } \\
\text { [Total hardness] }\end{array}$ & - & 30.7 & 4.39 \\
\hline $\mathrm{Cl}$ & 4 & 1397.2 & 3.992 \\
\hline $\mathrm{Mg}$ & 3 & 81.4 & 1.628 \\
\hline $\mathrm{Fe}$ & 3 & 3.20 & 10.7 \\
\hline
\end{tabular}

По формуле 3 были рассчитаны средние значения СПЗ (рис.10). Выявлено, что средние значения СПЗ водоносного турон-коньякского карбонатного комплекса варьируют от 0 до 4.72 .

Оценка качества подземных вод водоносного турон-коньякского карбонатного комплекса произведена на основании анализа максимальных концентраций, загрязняющих в подземных водах (табл. 3).

По результатам проведения эколого-гидрогеохимической оценки состояния водоносного турон-коньякского карбонатного комплекса были выявлены превышения концентраций ряда загрязняющих веществ, максимальные из которых представлены в табл. 2 (анализ загрязнения по средним показателям представлен выше). Состояние подземных вод оценивается как высоко опасное, что установлено по максимальной концентрации железа - 3.2 мг/дм³ (10.7 ПДК). Максимальное значение суммарного показателя загрязнения зафиксировано в октябре 2018 г. и составляет 10.7, что также свидетельствует о высоко опасном состоянии подземных вод (оценка степени комфортности жизнедеятельности - экологический кризис).

\section{Эколого-гидрогеофизическая оченка подземных вод водоносного турон- коньякского карбонатного комплекса}

В результате проведения эколого-геофизической оценки отмечается отсутствие превышений нормативов. Состояние подземных вод оценивается как допустимое. Удельная суммарная $\alpha$-активность варьирует от 0.09 до 0.11 Бк/л, удельная суммарная $\beta$ активность - от 0.15 до 0.17 Бк/л, удельная активность радона-222 - от 6.9 до 7.9 Бк/л.

\section{Эколого-гидродинамическая оченка подземных вод водоносного турон- коньякского карбонатного комплекса}

По площади своего распространения изучаемой водоносный комплекс характеризуется, как неограниченный, так как имеет повсеместное распространение на описываемой территории.

Водовмещающими породами служат белые писчие мела трещиноватые, мощностью 35 м. Трещиноватость меловых пород значительно изменяется по площади и в разрезе.

В целом, для рассматриваемого района характерно закономерное повышение водообильности комплекса в направлении от водоразделов к более низким отметкам рельефа, что определяется увеличением площади водосбора и скорости движения подземных вод на склонах речных долин.

Осредненное значение коэффициента водопроводимости вскрытой толщи на исследуемом водозаборе $-17 \mathrm{M}^{2} /$ сут.

Питание водоносного турон-коньякского комплекса происходит за счет инфильтрации атмосферных 
осадков, а также за счет перетекания вод из других водоносных горизонтов. Поток подземных вод комплекса направлен от водораздельной части к основным дренам - р. Черная Калитва и р. Дон.

Размеры территории схематизации определяются взаимным расположением естественных гидродинамических границ. Принимается схема неограниченного безнапорного пласта.

По сложности геолого-гидрогеологических условий участок месторождения отнесён ко II группе сложности по гидрогеохимическим и гидродинамическим показателям. Данное обстоятельство обусловлено приуроченностью к трещиноватым карбонатным породам с не простыми гидрохимическими условиями.

Основными гидрогеологическим параметрами для оценки возможности получения заявленного объема воды гидродинамическим методом являются:

- коэффициент водопроводимости $(\mathrm{km})$;

- коэффициент уровнепроводности $\left(\mathrm{a}_{\mathrm{y}}\right)$;

- мощность водоносного горизонта (m);

- допустимое понижение $\left(\mathrm{S}_{\text {доп }}\right)$;

- проектная нагрузка на проектную скважину $\left(\mathrm{Q}_{0}\right)$.

Мощность водоносного горизонта

Средняя мощность водоносного горизонта определена по данным бурения разведочно-эксплуатационных скважин: $m=20$ м.

\section{Коэффициент водопроводимости}

Расчёт коэффициента водопроводимости производился по результатам опытной откачки из скважины по графикам временного прослеживания при восстановлении и понижении уровня подземных вод

Временное прослеживание $\mathrm{S}-\lg \mathrm{t}$

Принцип расчета:

Строим график, на оси абсцисс которого откладываем логарифмы времени, а на оси ординат понижения уровня, получаем прямую с угловым коэффициентом $C$.

Коэффициент $C$ определяем по формуле:

$$
C=\frac{S_{2}-S_{1}}{\lg t_{2}-l q t_{1}} .
$$

Определив $C$ по формуле рассчитываем К по формуле:

$$
K_{\phi} m=\frac{0,183 Q}{C} .
$$

Результаты расчётов водопроводимости приведены ниже:

$\mathrm{s}^{*}-\lg$ t по восстановлению уровня $-18.1 \mathrm{~m}^{2} /$ сут;

$\mathrm{s}-\lg$ t по понижению уровня - $15.9 \mathrm{~m}^{2} /$ сут.

Таким образом, значение водопроводимости для водоносного турон-коньякского карбонатного комплекса составило $17 \mathrm{~m}^{2} /$ сут.

Коэффициент уровнепроводности

Коэффициент уровнепроводности принимается по фондовым и литературным данным: для безнапорных вод при $\mathrm{Km} \leq 100 \mathrm{~m}^{2} /$ сут , $\mathrm{a}=10^{4} \mathrm{M}^{2} /$ сут [12].

\section{Обоснование расчетного дебита} эксплуатационных скважин

Прогнозный дебит водозабора, по данным лицензии на геологическое изучение составляет $353.7 \mathrm{~m}^{3} / \mathrm{cyт}$. В пересчете на каждую из 3-х скважин производительность будет составлять 117.9 м $^{3} /$ сут.

\section{Допустимое понижение уровня}

Допустимое понижение $\left(\mathrm{S}_{\text {доп }}\right)$ определялось для участка водозабора, исходя из 0.5 мощности водоносного горизонта и величины напора (величина напора по скважинам варьирует от 15 до 19 м).

За допустимое понижение принимается величина (усреднённая): $\mathrm{S}_{\text {доп }}=27.7$ м.

В итоге, для расчета понижения уровня подземных вод (УПВ) и обоснования обеспеченности запасов подземных вод на весь срок эксплуатации водозабора, приняты следующие гидрогеологические (гидродинамические) параметры: $\mathrm{m}=20$ м., $\mathrm{Km}=17 \mathrm{M}^{2} /$ сут; $\mathrm{a}_{\mathrm{y}}=10^{4}$ $\mathrm{M}^{2} /$ сут $\mathrm{t}=10000$ сут., $\mathrm{S}_{\text {доп }}=27.7$.

\section{Основные исходные данные} по поисковому участку

- Проектный дебит эксплуатационной скважины, $\mathrm{Q}=117.9 \mathrm{~m}^{3} /$ сут;

- Количество эксплуатационных скважин, $\mathrm{n}=3$;

- Суммарный дебит водозаборного ряда, $\mathrm{Q}_{\text {вод }}=353.7$ $\mathrm{M}^{3} /$ сут;

- Длина водозаборного ряда, $l=250$ м;

- Допустимое понижение, $\mathrm{S}_{\text {доп }}=27.7 \mathrm{~m}$

- Мощность водоносного комплекса, $\mathrm{m}=20.0 \mathrm{M}$;

- Коэффициент водопроводимости, $\mathrm{km}=17.0 \mathrm{~m} / \mathrm{cyт}$;

- Коэффициент пьезопроводности, $\mathrm{a}=10^{4} \mathrm{M}^{2} /$ сут.

1. Понижение, вызванное внешним воздействием системы:

$$
S_{\text {об }}=\frac{353.70}{4 \times 3.14 \times 17.0} \ln \frac{2.25 \times 10^{4} \times 10^{4}}{(0.2 \times 250)^{2}}=18.89 \mu .
$$

2. Дополнительное понижение уровня в скважине будет составлять:

$$
S_{c \kappa}=\frac{117.9}{4 \times 3.14 \times 17.0} 2\left(\ln \frac{\frac{50+75}{2 \times 3.14}}{0.273}+0.5\right)=5.29 \text { м. }
$$

3. Общее понижение в водоносном комплексе составит:

$$
S_{\text {pacu }}=18.89+5.29=24.18 \mathrm{M} \text {. }
$$


Таким образом, полученное расчетное понижение уровня $S_{\text {расч }}=24.18$ м меньше величины допустимого понижения $-\mathrm{S}_{\text {доп }}=27.7$ м., что свидетельствует о возможности добычи подземных вод в объеме 353.70
$\mathrm{M}^{3} /$ сут в течение 25 лет (10000 суток).

В соответствии с формулой 11 , произведен расчет гидродинамического потенциала водозабора при сохранении существующей системы водоснабжения:

$$
Q_{c y M}=\frac{12 \times 27.7 \times 3.14 \times 17}{3 \ln \frac{2.25 \times 10^{4} \times 10^{4}}{(0.2 \times 250)^{2}}+2\left(\ln \frac{\frac{50+75}{2 * 3.14}}{0.273}+0.5\right)}=405.09 \mathrm{M}^{3} / \mathrm{cym} .
$$

Таким образом, нормативный расчет водопотребления с учетом перспективы развития может быть равным $405.09 \mathrm{~m}^{3} /$ сут.

\section{Разработка природоохранных мероприятий для обеспечения качества питьевых вод}

На основании произведенной оценки были сформированы природоохранные мероприятия, которые отображены на рис. 11.

\section{Заключение}

В результате проведенных исследований была дана эколого-гидрогеологическая оценка состояния подземных вод водоносного турон-коньякского карбонатного комплекса в районе села Старая Калитва Россошанского района Воронежской области.

Основные тезисы и выводы приведены на рис. 11.

В качестве основных природоохранных мероприятий выделяются:

- установка системы обратного осмоса;

- сохранение ресурса подземных вод;

- мониторинг качества водоносного турон-коньякского карбонатного комплекса 4 раза в год (по сезонам года (межень/паводок)) с обязательным контролем концентраций следующих компонентов: железо общее, хлориды, магний, сухой остаток, общая жесткость и мутность;

- запрет добычи подземных вод в объеме превышающим $405.09 \mathrm{~m}^{3} /$ сут;

- контроль $3 \mathrm{CO}$ 1,2,3 поясов, соответственно радиусов 30 м, 86.7 м, 1061.3 м.

Данная статья базировалась на оценке экологогидрогеологического состояния водоносного туронконьякского карбонатного комплекса посредством изучения экологических функций подземных вод [1] В работе [13] эколого-гидрогеологическая оценка также была дана путем анализа экологических функций подземных вод. Однако, результаты вышеприведенных работ показали, что учение о экологических функциях литосферы сложно согласуется с реальной оценкой экологического состояния подземных вод.

Так, в реальных условиях, размеры ЗСО рассчитываются комплексно по результатам химической, органолептической, радиологической и бактериологической оценки. В приведенной методике, данные параметры должны быть разделены. Тем не менее, расчет ЗСО может быть произведен только при совместном рассмотрении всех показателей. То есть, их выделение теряет значимость. Второй пояс $3 \mathrm{CO} \mathrm{учитывает} \mathrm{бакте-}$ риологический фактор, а третий - химический, то есть, согласно учению о экологических функциях литосферы, эти параметры могут быть отнесены к разным функциям (в данной статье два показателя были отнесены к ресурсной экологической функцией литосферы). Проект ЗСО, в реальных условиях, согласуется, в первую очередь, санитарно-эпидемиологической службой и является единой процедурой оценки качества воды, по результатам которой выдается заключение о соответствии/несоответствии проекта санитарно-эпидемиологическим правилам и нормам.

В случае несоответствия подземных вод по радиологическим показателям существующим нормативам это можно связать с химическим загрязнением подземных вод радиоактивными веществами, а это уже химическое загрязнение (геохимическая экологическая функция подземных вод).

Геодинамическая экологическая функция подземных вод была обозначена в работах как экологогидродинамическая (что связано с попыткой увязать данную функцию с существующей методикой оценки и базовыми понятиями гидрогеологии).

Ресурсная экологическая функция и эколого-гидродинамическая функция водоносного турон-коньякского карбонатного комплекса трудно разделимы в реальных условиях. Так, например, мощность обводненных отложений, величина напора, удельные дебиты скважин, коэффициент водопроводимости, коэффициент уровнепроводности, допустимое понижение уровня подземных вод и другие параметры можно отнести как к ресурсной, так и к эколого-гидродинамической функции. Следует отметить, что о «проблемах» отнесения тех или иных параметров к определенной функции и их тесной связи написано в работе [1].

Эколого-гидрогеохимическая функция содержит в себе оценку качества подземных вод, на основании которой делается вывод о возможности эксплуатации подземных вод, что относится уже к ресурсной экологической функции.

Таким образом, экологические функции подземных вод очень тесно «переплетены» и в реальных условиях выделить их в «чистом» виде, практически невозможно. Эколого-гидрогеологическая оценка, согласно [1] опосредовано связана с реальной (практической) ситуацией и ее применение не дает новых результатов. Практически невозможно выделить ресурсную, геофизическую, геохимическую и геодинамическую 
Ресурсная экологическая оценка водоносного турон-коньякского карбонатного комплекса

Водовмещающие породы: мела трещиноватые. Средняя мощность обводненных отложений $-20 \mathrm{M}$, величина напора - 15.0 19.0 м. Общее количество скважин - 3.

Размер 3СО 1 пояса - $30 \mathrm{M}$. Размер 3СО 2 пояса $-86.7 \mathrm{M}$. Размер 3СО 3 пояса $-1061.3 \mathrm{M}$. Бактериологические показатели

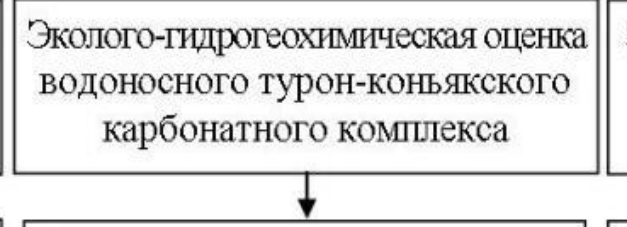

Вода оценивается как умеренно опасная. Отмечается несоответствие нормативам по:

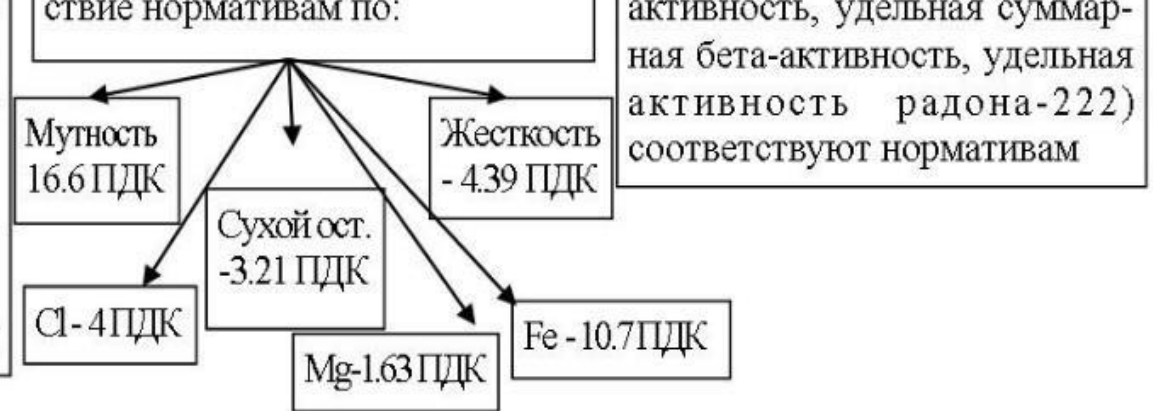

Эколого-геофизическая оценка водоносного турон-коньякского карбонатного комплекса

Радиологические анализы Радиологические анализы
(удельная суммарная альфаактивность, удельная суммарная бета-активность, удельная

)

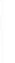
водности $-10^{4} \mathrm{M}^{2} /$ сут. Допустимое понижение составляет 27,7 м. Расчетное понижения уровня подземных вод составляет 24.18 м. Максимально допустимое водопотребление $405.09 \mathrm{M}^{3} /$ cyт.
Эколого-гидродинамическая оценка водоносного турон-коньякского карбонатного комплекса

Удельный дебит скважин составляет $0,14 \mathrm{~J} / \mathrm{c} / \mathrm{M}$. Коэффициставляет 0,14 л/с/м. Коэффицн-

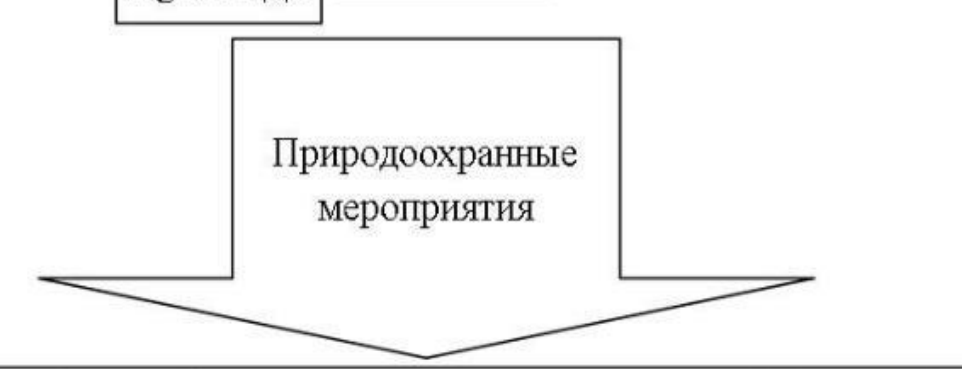

Установка системы водоподготовки: обратный осмос. Сохранение ресурса подземньг вод. Контроль ЗСО. Мониторинг качества водоносного турон-коньякского карбонатного комплекса 4 раза в год (по сезонам года (межень/паводок)). Обязательные вещества для контроля: $\mathrm{Fe}$, $\mathrm{Cl}$, сухой остаток, общая жесткость, мутность, Мg. Радиологические анализы - не реже 1 раз в год. Возможность увеличения водопотребления с учетом перспективы развития до $405.09 \mathrm{~m}^{3} /$ сут. Контроль динамического и статического уровней подземньх вод не реже 1 раза в месяц.

Рис. 11. Эколого-гидрогеологическая оценка состояния водоносного турон-коньякского карбонатного комплекса в с. Старая Калитва Россошанского района Воронежской области и схема природоохранных мероприятий.

[Fig. 11. Environmental protection scheme for the aquifer Turonian-Cognac carbonate complex.] 
экологические функции подземных вод, они во многом не самостоятельны и их раздельная оценка дает фрагментарные выводы. Более того, оценка экологических функций подземных вод вносит определенные трудности и сложности (обозначенные выше) в методику оценки и, что самое главное, практически не приносит новых результатов. Если брать данную методику в качестве основы для оценки, то возникают трудности, решить которые чрезвычайно сложно. В этой связи, эколого-геологическая оценка состояния подземных вод как в научных, так и практических целях, как правило, дается без учета существующего учения об экологических функциях литосферы. Даже законодательные требования к оценке запасов подземных вод не ссылаются на данное учение.

$\mathrm{C}$ нашей точки зрения, учение об экологических функциях литосферы должно создавать «фундамент», основу экологической геологии. Но, в ситуации с подземными водами, данная теория дает лишь общее представление о методике оценки подземных вод и очень слабо связана с реальными существующими подходами, применяемыми при экологической оценке.

В этой связи, необходимо отметить, что на данный момент учение об экологических функциях литосферы [1], при всей своей обоснованности и структурированности, трудно применимо для эколого-геологической оценки состояния подземных вод и нуждается в дальнейшем развитии и обеспечении связи с реальной эколого-гидрогеологической ситуацией на местности.

Конфликт интересов: Авторы декларируют отсутствие явных и потенциальных конфликтов интересов, связанных с публикацией настоящей статьи.

\section{ЛИТЕРАТУРА}

1. Трофимов В. Т., Зилинг Д. Г. Экологическая геология: Учебник для студ. геол. специальностей вузов; М-во природ. ресурсов Рос. Федерации. Моск. гос. ун-т им. М.В. Ломоносова. М.: Геоинформмарк, 2002. 414 с.

2. Косинова И. И., Белозеров Д. А. Методика оценки трансформации верхних водоносных горизонтов в зоне влияния предприятий по производству минеральных удобрений. Труды научно-исследовательского института геологии:
Воронеж, Изд-во Воронеж. гос. ун-та. Вып. 84, 2014. 121 с. 3. Косинова И. И., Кустова Н. Р. Теория и методология геоэкологических рисков // Вестник Воронежского государственного университета. Серия: Геология. 2008. № 2. С. 189-197.

4. Косинова И. И., Богословский В.А., Бударина В.А. Методы эколого-геохимических, эколого-геофизических исследований и рациональное недропользование: учебное пособие для студ. вузов, обуч. по направлению 511000 "Геология" и университетским геол. специальностям. Воронеж, Изд-во гос. ун-та. 2004. 279 с.

5. Косинова И. И., Базарский О.В., Козинцев С.Н. Методика геоэкологической биоиндикации георисков техногеннотрансформированных территорий // Геориск. 2012. № 3. С. $22-25$.

6. Боревский Б. В., Дробноход Л.С., Язвин Л.С. Оценка запасов подземных вод: Учебник для студ. геолог. фак-тов ун-тов и горных вузов. Киев: Выща школа. 1989. 407 с

7. Белицкий А. С. Краткий справочник по проектированию и бурению скважин на воду 2-е издание. М., Недра. 1983. 77 с. 8. Савко А. Д. Геология Воронежской антеклизы. Труды научно-исследовательского института геологии: Воронеж, Изд-во Воронеж. гос. ун-та. Вып. 12. 2002. 165 с.

9. Бочаров В. Л., Зинюков Ю.М., Смоляницкий Л.А. Мониторинг природно-технических экосистем (на примере ОАО "Минеральные удобрения"). Воронеж. гос. ун-т: Воронеж, Истоки, 2000. 226 с.

10. Санитарно-эпидемиологические правила и нормативы. СанПиН 2.1.4.1074.01 «Питьевая вода. Гигиенические требования к качеству воды централизованных систем водоснабжения. Контроль качества». Госкомэпиднадзор России. М. 2002 г.

11. Белозеров Д. А. Микрокомпонентный анализ качества подземных вод южной части левого берега города Воронежа // Вестник Воронежского государственного университета. Серия: Геология. 2017. № 1. С. 130-134.

12. «Оценка эксплуатационных запасов питьевых и технических подземных вод по участкам недр, эксплуатируемым одиночными водозаборами», Методические рекомендации ГИДЭК, 2002. 61 с.

13. Белозеров Д. А., Бударина В. А., Курышев А. А. Экологогидрогеологическая оценка состояния водоносного верхнеплиоценового терригенного горизонта в районе Медовка Рамонского района Воронежской области. // Вестник Воронежского государственного университета. Серия: Геология. 2019. № 2. С. 107-117. 


\title{
Ecological and hydrogeological assessment of the state of groundwater in the aquiferous Turonian-Coniacian carbonate complex near the village of Staraya Kalitva in the Rossosh district of the Voronezh region
}

\author{
@2020 D. A. Belozerov ${ }^{\bowtie}$, V. A. Budarina, A. A. Valyalshchikov \\ Voronezh State University \\ 1 Universitetskaya pl., 394018 Voronezh, Russian Federation
}

\begin{abstract}
Introduction: The aim of the study was the ecological and hydrogeological assessment of the state of groundwater in the aquiferous Turonian-Coniacian carbonate complex near the village of Staraya Kalitva in the Rossosh district of the Voronezh region.

Methodology: The assessment of the state of the aquiferous Turonian-Coniacian carbonate complex was based on the study of the ecological functions of groundwater. The resource ecological state of the aquiferous Turonian-Coniacian carbonate complex was assessed based on the calculation and analysis of the following parameters: the lithology of water-bearing rocks, the thickness of the aquifer, the depth of groundwater occurrence, the position of the static level; the size of the sanitary protection zones of groundwater, bacteriological characteristics of groundwater, and organoleptic characteristics of groundwater. The ecological and hydrogeochemical assessment of the aquiferous Turonian-Coniacian carbonate complex was based on comparing the actual concentrations of substances with the maximum permissible concentrations, calculating the average and maximum values of the total pollution index. The quality of groundwater was monitored from 2012 to 2019 . The ecological and geophysical assessment of groundwater was carried out considering the following indicators: specific total $\alpha$-activity, specific total $\beta$-activity, and specific activity of radon-222. The ecological and hydrodynamic assessment of the aquiferous Turonian-Coniacian carbonate complex was based on the calculation of the main hydrodynamic parameters.

Results and discussion: For the research, 3 exploration and production wells with a depth of $95 \mathrm{~m}$ each were used. It was found that the water-bearing rocks were represented by $20 \mathrm{~m}$ thick jointing Cretaceous deposits, the pressure head is $15-19$ meters. The size of the sanitary protection zones of the first ring is 30 $\mathrm{m}$, the second ring is $86.7 \mathrm{~m}$, and the third ring is $1061.3 \mathrm{~m}$. According to the results of the assessment, excessive values were recorded for the following indicators: turbidity (16.6 MPC), dry residue (3.21 MPC), total hardness (4.39 MPC), chlorides (4 MPC), magnesium (1.63 MPC), and total iron (10.7 MPC). As a result of the ecological and hydrodynamic assessment, it was determined that the specific discharge of wells is $0.14 \mathrm{l} / \mathrm{s} / \mathrm{m}$, the water transmissivity coefficient is $17 \mathrm{~m}^{2} /$ day, the coefficient of layer conductivity is $10^{4}$ $\mathrm{m}^{2} /$ day, the permissible decrease is $27.7 \mathrm{~m}$, the estimated lowering of the groundwater level is $24.18 \mathrm{~m}$, and the maximum permissible water consumption is $405.09 \mathrm{~m}^{3} /$ day. The maximum excess of the content of pollutants in groundwater was recorded for the concentration of iron: $3.2 \mathrm{mg} / \mathrm{dm}^{3}$ (10.7 MPC), and the total pollution index, which is 10.7 .

Conclusions: Based on the results of the assessment, a set of environmental protection measures was designed. One of the main measures is the installation of a reverse osmosis system to reduce the concentration of chlorides, magnesium, iron, dry residue, as well as to reduce the hardness and turbidity. A conclusion was made about the issues of applying the existing theory of studying the ecological functions of the lithosphere to the assessment of the ecological state of groundwater. The study demonstrated the need to revise the theory and ensure the correlation between the theory and the real situation.
\end{abstract}

The content is available under Creative Commons Attribution 4.0 License.

\footnotetext{
${ }^{凶}$ Denis A. Belozerov, e-mail: belozerovdenis@yandex.ru
} 
Keywords: Groundwater, aquiferous Turonian-Coniacian carbonate complex, ecological function of groundwater, ecological and hydrogeological assessment, groundwater quality, zones of sanitary protection, environmental protection measures.

For citation: Belozerov D. A., Budarina V. A., Valyalshchikov A. A. Ecological and hydrogeological assessment of the state of groundwater in the aquiferous Turonian-Coniacian carbonate complex near the village of Staraya Kalitva in the Rossosh district of the Voronezh region. Vestnik Voronezhskogo gosudarstvennogo universiteta. Seriya: Geologiya = Proceedings of Voronezh State University. Series: Geology. 2020, No.3, pp. 73-89. DOI: https://doi.org/10.17308/geology.2020.3/3011

Conflict of interests: The authors declare the absence of obvious and potential conflicts of interest related to the publication of this article.

\section{REFERENCES}

1. Trofimov V. T., Ziling D. G. Ekologicheskaya geologiya [Ecological geology]. Moscow, MSU publ. Geoinformmark, 2002. 414 p. (In Russ.)

2. Kosinova I. I., Belozerov D. A. Metodika otsenki transformatsii verkhnikh vodonosnykh gorizontov $\mathrm{v}$ zone vliyaniya predpriyatiy po proizvodstvu mineral'nykh udobreniy [Methods for assessing the transformation of upper aquifers in the zone of influence of enterprises for the production of mineral fertilizers]. Trudy Nauchnoissledovatel'skogo Instituta Geologii [The work of the Research Institute of Geology], Voronezh, VSU Publ., vol. 84, 2014, 121 p. (In Russ.)

3. Kosinova I. I., Kustova N. R. Theory and methodology of geoecological risks. Vestnik Voronezhskogo gosudarstvennogo universiteta. Seriya: Geologiya $=$ Proceedings of Voronezh State University. Series: Geology. 2008, no. 2, pp. 189-197. (In Russ.) 4. Kosinova I. I., Bogoslovskiy V. A., Budarina V. A. Metody ekologo-geokhimicheskikh, ekologo-geofizicheskikh issledovaniy ratsional'noe nedropol'zovanie [Methods of ecological and geochemical, ecological and geophysical research and rational use of mineral resources]. Voronezh, VSU publ., 2004. 279 p. (In Russ.)

5. Kosinova I. I., Bazarskij O. V., Kozincev S. N. Metodika geoekologicheskoy bioindikatsii georiskov tekhnogenno-transformirovannykh territoriy [Methodology of geoecological bioindication of geo-risks of technogenically transformed territories]. Georisk = Georisk. 2012, no. 3, C. 22-25. (In Russ.)

6. Borevskiy B. V., Drobnokhod L. S., Yazvin L. S. Otsenka zapasov podzemnykh vod [Assessment of groundwater reserves]. Kiev, Vysshaya shkola 1989, 407 p. (In Russ.)

7. Belitskiy A. S. Kratkiy spravochnik po proektirovaniyu i bureniyu skvazhin na vodu [A short guide to the design and drilling of water wells]. Moscow, Nedra, 1983, 77 p. (In Russ.)
8. Savko A. D. Geologiya Voronezhskoj anteklizy [Geology of the Voronezh anteclise]. Trudy Nauchno-issledovatel'skogo Instituta Geologii [The work of the Research Institute of Geology], Voronezh, VSU Publ., vol. 12, 2002, 165 p. (In Russ.)

9. Bocharov V. L., Zinyukov Yu. M., Smolyanitskiy L. A. Monitoring prirodno-tekhnicheskikh ekosistem (na primere OAO "Mineral'nye udobreniya") [Monitoring of natural and technical ecosystems (on the example of OJSC "Mineral Fertilizers")]. Voronezh, Istoki publ., 2000, 226 p. (In Russ.)

10. Sanitarno-epidemiologicheskie pravila $i$ normativy. SanPiN 2.1.4.1074.01 "Pit'evaya voda. Gigienicheskie trebovaniya $k$ kachestvu vody tsentralizovannykh sistem vodosnabzheniya. Kontrol' kachestva» [Sanitary and Epidemiological Rules and Regulations. SanPiN 2.1.4.1074.01 "Drinking water. Hygienic requirements for water quality in centralized water supply systems. Quality control"]. State Committee for Epidemiological Supervision of Russia. Moscow, 2002. (In Russ.)

11. Belozerov D. A. Microcomponent analysis of groundwater quality southern left bank Voronezh city // Vestnik Voronezhskogo gosudarstvennogo universiteta . Seriya: Geologiya $=$ Proceedings of Voronezh State University. Series: Geology. 2017, no 1, pp. 130-134. (In Russ.)

12. «Otsenka ekspluatatsionnykh zapasov pit'evykh i tekhnicheskikh podzemnykh vod po uchastkam nedr, ekspluatiruemym odinochnymi vodozaborami» ["Assessment of the operational reserves of drinking and technical groundwater for the subsoil areas operated by single water intakes"]. Guidelines, GIDEK, 2002, 61 p. (In Russ.)

13. Belozerov D. A., Budarina V. A., Kuryshev A. A. Ecologicalhydrogeochemical assessment of the aqueous upper pliocene terrigenous horizon condition in the area of the village Medovka Ramonsky district of Voronezh region. Vestnik Voronezhskogo gosudarstvennogo universiteta . Seriya: Geologiya $=$ Proceedings of Voronezh State University. Series: Geology. 2019, no. 2, pp. 107117. (In Russ.)
Белозеров Денис Александрович - к. г. н., доцент кафедры экологической геологии, Воронежский государственный университет; Воронеж, Российская Федерация;

E-mail: belozerovdenis@yandex.ru;

ORCID https://orcid.org/0000-0002-7098-7774

Бударина Виктория Александровна - к. ю. н., доцент кафедры экологической геологии, Воронежский государственный университет; Воронеж, Российская Федерация; E-mail: budarinav@yandex.ru; ORCID https://orcid.org/0000-0001-8091-0730

Валяльщиков Алексей Александрович - к.г.н., доцент кафедры экологической геологии, Воронежский государственный университет; Воронеж, Российская Федерация; E-mail: 770vaa@geol.vsu.ru; ORCID https://orcid.org/0000-0002-3787-4655

Авторы прочитали и одобрили окончательный вариант рукописи.
Denis A. Belozerov - PhD in Geography, Associate professor of Ecological Geology Department, Voronezh State University, Voronezh, Russian Federation;

E-mail: belozerovdenis@yandex.ru;

ORCID https://orcid.org/0000-0002-7098-7774

Victoria. A. Budarina - PhD in law, Associate professor of Ecological Geology Department, Voronezh State University, Voronezh; Russian Federation;

E-mail: budarinav@yandex.ru; ORCID https://orcid.org/0000-0001-8091-0730

Alexey. A. Valyalschikov - PhD in Geography, Associate professor of Ecological Geology Department, Voronezh State University, Voronezh;

E-mail: 770vaa@mail.ru;

ORCID https://orcid.org/0000-0002-3787-4655

All authors have read and approved the final manuscript. 